\title{
Phylogenetic analysis and identification of Aeromonas species based on sequencing of the cpn60 universal target
}

\author{
Correspondence \\ J. Gaspar Lorén \\ jgloren@ub.edu
}

\author{
David Miñana-Galbis, Aintzane Urbizu-Serrano, Maribel Farfán, \\ M. Carmen Fusté and J. Gaspar Lorén
}

\author{
Departament de Microbiologia i Parasitologia Sanitàries, Facultat de Farmàcia, Universitat de \\ Barcelona, Av. Joan XXIII s/n, 08028 Barcelona, Spain
}

\section{INTRODUCTION}

Classification of the genus Aeromonas, which belongs to the Gammaproteobacteria, remains complex from a taxonomic point of view because of the continuous description of novel species, the rearrangement of strains and species described so far and the discrepancies observed in different DNA-DNA hybridization studies (Huys et al., 1997, 2001, 2005; Martínez-Murcia, 1999; Esteve et al., 2003; MiñanaGalbis et al., 2007). Sequence analysis of different housekeeping genes has been recommended for species delineation in addition to DNA-DNA hybridization in order to increase discriminatory power and the robustness of phylogenetic relationships with regard to 16S rRNA gene sequence analysis (Stackebrandt et al., 2002). Recent studies based on the sequences of $d n a J, g y r B, r p o B$ and

Abbreviation: UT, universal target.

The GenBank/EMBL/DDBJ accession numbers for the cpn60 UT sequences determined in this study are detailed in Table 1.

Scatter plots of JC69 distances and an extended consensus neighbourjoining tree of cpn60 UT sequences are available as supplementary material with the online version of this paper. $r p o D$ have shown that the use of several housekeeping genes is an effective approach for the classification of Aeromonas species (Küpfer et al., 2006; Saavedra et al., 2006; Nhung et al., 2007).

The type I chaperonin Cpn60 (Hsp60 or GroEL) is a highly conserved protein found in bacteria, some archaea and organelles of endosymbiotic origin. Overexpressed under physiologically stressful conditions, it has been described as an intercellular signalling molecule and a potent immunogen, and has been implicated in inflammatory diseases (Hill et al., 2004; Wick et al., 2004; Horwich et al., 2007). Analyses of cpn60 sequences are useful for microbiological studies using different approaches, such as phylogeny, microbial detection and identification, as well as microbial ecology and evolution (Hill et al., 2006; Thompson et al., 2005; Fares \& Travers, 2006; Goyal et al., 2006; Gupta \& Sneath, 2007). Hill et al. (2004) have analysed sequences of this gene from a wide variety of bacterial, archaeal and eukaryotic species. They concluded that a $549-567$ bp region of the cpn60 gene (the universal target or UT), amplified by universal PCR primers, is representative of the complete gene (approx. $1600 \mathrm{bp}$ ) in terms of phylogeneti- 
cally informative sequence variation. Furthermore, these authors have designed and implemented a web-based chaperonin sequence database (cpnDB; http://cpndb. cbr.nrc.ca).

In the present study, we have sequenced and analysed a $555 \mathrm{nt}$ sequence, corresponding to the UT region of the cpn60 gene, in type and reference strains of all Aeromonas described to date. This should allow us to evaluate its applicability for species delineation and identification within Aeromonas. Sequencing of the cpn60 gene not only increases the number of housekeeping genes sequenced from Aeromonas species, but may also facilitate simple and rapid Aeromonas species identification.

\section{METHODS}

Bacterial strains. The Aeromonas strains used in this study for sequencing of the cpn60 UT region and their GenBank accession numbers are listed in Table 1 .

DNA extraction, PCR amplification and sequencing. DNA extraction was performed as described previously (Miñana-Galbis et al., 2007). PCR amplification and sequencing of the $c p n 60$ UT region were conducted using a modification of previously described methods (Brousseau et al., 2001; Hill et al., 2002). Two primers were used for PCR amplification and sequencing, C175 (5'-GAAATYGAACTGGAAGACAA- $\left.3^{\prime}\right)$ and C938 (5'-GTYGCTTTTTCCAGCTCCA- $\left.3^{\prime}\right)$. These primers were designed from the complete cpn60 sequences of Aeromonas salmonicida NCIMB 835 and Escherichia coli CFT073 (GenBank accession numbers AF030975 and NC_004431, respectively), and correspond to nucleotides 175-194 and 938-920, respectively, of the complete cpn60 gene. PCR amplification was carried out in a total volume of $50 \mu \mathrm{l}$ containing $50 \mathrm{mM} \mathrm{KCl}, 15 \mathrm{mM}$ Tris/HCl, pH 8.0, $1.5 \mathrm{mM} \mathrm{MgCl}_{2}, 0.25 \mathrm{mM}$ dNTPs (Amersham Biosciences), $2.5 \mathrm{U}$ AmpliTaq Gold DNA polymerase (Applied Biosystems) and $50 \mathrm{pmol}$ of each primer (Isogen Life Science). The reaction mixtures were subjected to the following thermal cycling program in a 2720 Thermal Cycler (Applied Biosystems): denaturation at $95{ }^{\circ} \mathrm{C}$ for $10 \mathrm{~min}, 35 \mathrm{cycles}$ of $94{ }^{\circ} \mathrm{C}$ for $1 \mathrm{~min}, 52{ }^{\circ} \mathrm{C}$ for $1 \mathrm{~min}$ and $72{ }^{\circ} \mathrm{C}$ for $1 \mathrm{~min}$ and a final extension step at $72{ }^{\circ} \mathrm{C}$ for $10 \mathrm{~min}$. The amplified products were purified using the MSB Spin PCRapace kit (Invitek) and sequencing was performed using the ABI PRISM BigDye Terminator v3.1 Cycle Sequencing kit (Applied Biosystems) with the following thermal cycling conditions: $96{ }^{\circ} \mathrm{C}$ for $1 \mathrm{~min}$ and 25 cycles of $96{ }^{\circ} \mathrm{C}$ for $10 \mathrm{~s}, 52{ }^{\circ} \mathrm{C}$ for $5 \mathrm{~s}$ and $60{ }^{\circ} \mathrm{C}$ for 4 min. Nucleotide sequences were determined in an ABI PRISM 3730 DNA analyser by the Genomics Unit of the Scientific and Technical Services of the University of Barcelona.

Data analyses. Multiple DNA and protein alignments were obtained by using CLUSTAL w software (Thompson et al., 1994). DNA polymorphism data and $\mathrm{G}+\mathrm{C}$ content determination were conducted with DnaSP software (Rozas \& Rozas, 1999). Phylogeny calculations, including synonymous and non-synonymous substitutions, the $Z$-test of neutrality $(\mathrm{dS}=\mathrm{dN})$ and neighbour-joining and maximum-parsimony trees of DNA sequence alignments were performed using MEGA software, version 3.1 (Kumar et al., 2004). Escherichia coli sequences were used as an outgroup. Statistical analysis, including correlations and regression analysis, were conducted using Excel XP (Microsoft) and R computing language (Ihaka \& Gentleman, 1996). When applied, bootstrap analysis was computed with 1000 replicates.

\section{RESULTS AND DISCUSSION}

\section{Comparative analysis of cpn60 UT sequences}

In this study, we sequenced the UT region of the cpn60 gene, a $555 \mathrm{bp}$ fragment corresponding to positions $274-828$ of the complete gene, in 35 strains representing all species and subspecies of the genus Aeromonas (Table 1). The same two primers designed in this study were used for amplification and sequencing. Analyses of these 35 sequences (Table 2) revealed 32 unique sequences; no insertions or deletions were detected. These sequences exhibited 189 polymorphic sites $(34.1 \%), 136$ of which were parsimony-informative sites, with a total number of 274 mutations. The pairwise differences ranged from 0 to 111 nucleotides (0-20\%), with the mean number of nucleotide differences of $57.2 \pm 4.0$. In accordance with Nei (1996), distances were calculated based on the Jukes-Cantor (JC69) model (Jukes \& Cantor, 1969), since the number of nucleotides was high $(n>500)$, the number of nucleotide substitutions per site $(d)$ was below $0.25(0.233)$ and the transition to transversion ratio $(R)$ was less than five $(R=2.0)$.

Using the same collection of Aeromonas strains, analyses of cpn60 sequences were compared to those obtained from gyrB, $r p o D$ and 16S rRNA genes, either sequenced previously in our laboratory or taken from GenBank. The range and mean pairwise JC69 distances for these genes are shown in Table 2. Differences between distances obtained when comparing all four genes were statistically significant $(P<0.001$; Wilcoxon's signed rank test $)$ and, although the range of sequence divergences of cpn60 was smaller than those of $\operatorname{gyr} B$ and $r p o D$, they proved significantly greater than that of the 16S rRNA gene. Correlations and regression curves between pairwise JC69 distances of cpn60, gyrB, rpoD and 16S rRNA gene sequences were generated by Pearson's product-moment correlation coefficient (Supplementary Fig. S1, available in IJSEM Online). A significant correlation was obtained between the different genetic loci $(r>0.6, \quad P<0.001)$. The test for synonymous and non-synonymous analysis $(\mathrm{dS}=\mathrm{dN}$ for a null hypothesis and $\mathrm{dS}>\mathrm{dN}$ for an alternative hypothesis) was highly significant $(P<0.001)$, indicating the presence of purifying selection (Table 2 ).

After conducting a pairwise comparison of cpn60, gyrB, $r p o D$ and $16 \mathrm{~S}$ rRNA gene sequences (595 comparisons), we calculated the percentage divergence of the number of nucleotide differences per sequence (Fig. 1). Histograms represent the sequence divergence of the pairwise comparisons for the 35 strains included in this study. The distance matrix for $c p n 60$ showed six distances of 0 with respect to the 14 obtained for the 16S rRNA gene. In the case of $g y r B$ and $r p o D$, all distances were above 0 . Moreover, the divergence distribution of cpn60 was smoother than those of the other genes compared.

As cpn60 was initially proposed as a possible alternative to the 16S rRNA gene (Hill et al., 2004), these results demonstrate that the cpn60 UT sequences provide much 
Table 1. Aeromonas strains used for $c p n 60$ UT sequencing

\begin{tabular}{|c|c|}
\hline Strain & $\begin{array}{c}\text { GenBank acces- } \\
\text { sion number }\end{array}$ \\
\hline \multicolumn{2}{|l|}{ A. allosaccharophila } \\
\hline CECT $4199^{\mathrm{T}}$ & EU306795 \\
\hline CECT 4200 & EU741624 \\
\hline \multicolumn{2}{|l|}{ A. bestiarum } \\
\hline $112 \mathrm{~A}^{*}$ & EU741625 \\
\hline $628 \mathrm{~A}^{*}$ & EU306797 \\
\hline CECT $4227^{\mathrm{T}}$ & EU306796 \\
\hline \multicolumn{2}{|l|}{ A. bivalvium } \\
\hline $665 \mathrm{~N}$ & EU306798 \\
\hline $868 \mathrm{E}^{\mathrm{T}}$ & EU306799 \\
\hline \multicolumn{2}{|l|}{ A. caviae } \\
\hline $\mathrm{A} 10 \mathrm{Cl}^{*}$ & EU741626 \\
\hline $706 \mathrm{OP}^{\star}$ & EU741627 \\
\hline CECT $838^{\mathrm{T}}$ & EU306800 \\
\hline A. culicicola CIP $107763^{\mathrm{T}}$ & EU306840 \\
\hline \multicolumn{2}{|l|}{ A. encheleia } \\
\hline CECT $4342^{\mathrm{T}}$ & EU306801 \\
\hline CECT 4343 & EU741628 \\
\hline CECT 4824 & EU741629 \\
\hline \multicolumn{2}{|l|}{ A. enteropelogenes } \\
\hline CECT $4487^{\mathrm{T}}$ & EU306837 \\
\hline CECT 4935 & EU741630 \\
\hline CECT 4936 & EU741631 \\
\hline CECT 4937 & EU741632 \\
\hline \multicolumn{2}{|l|}{ A. eucrenophila } \\
\hline CECT $4224^{\mathrm{T}}$ & EU306803 \\
\hline CECT 4853 & EU741633 \\
\hline CECT 4854 & EU741634 \\
\hline A. hydrophila CECT 5236 & EU741635 \\
\hline \multicolumn{2}{|l|}{ A. hydrophila subsp. dhakensis } \\
\hline CECT $5744^{\mathrm{T}}$ & EU306806 \\
\hline LMG 19558 & EU741636 \\
\hline A. hydrophila subsp. hydrophila CECT $839^{\mathrm{T}}$ & EU306804 \\
\hline A. hydrophila subsp. ranae CIP $107985^{\mathrm{T}}$ & EU306805 \\
\hline A. ichthiosmia CECT $4486^{\mathrm{T}}$ & EU306841 \\
\hline \multicolumn{2}{|l|}{ A. jandaei } \\
\hline CECT $4228^{\mathrm{T}}$ & EU306807 \\
\hline CECT 4813 & EU741637 \\
\hline CECT 4814 & EU741638 \\
\hline CECT 4815 & EU741639 \\
\hline CECT 4838 & EU741640 \\
\hline \multicolumn{2}{|l|}{ A. media } \\
\hline CECT $4232^{\mathrm{T}}$ & EU306808 \\
\hline CECT 4234 & EU741641 \\
\hline \multicolumn{2}{|l|}{ A. molluscorum } \\
\hline $093 \mathrm{M}$ & EU306809 \\
\hline $431 \mathrm{E}$ & EU306810 \\
\hline $848 \mathrm{~T}^{\mathrm{T}}$ & EU306811 \\
\hline $849 \mathrm{~T}$ & EU306812 \\
\hline $869 \mathrm{~N}$ & EU306813 \\
\hline \multicolumn{2}{|l|}{ A. popoffii } \\
\hline LMG $17541^{\mathrm{T}}$ & EU306814 \\
\hline LMG 17542 & EU306815 \\
\hline LMG 17543 & EU306816 \\
\hline \multicolumn{2}{|l|}{ A. salmonicida } \\
\hline $083 C^{\star}$ & EU306817 \\
\hline
\end{tabular}

Table 1. cont.

\begin{tabular}{|c|c|}
\hline Strain & $\begin{array}{l}\text { GenBank acces- } \\
\text { sion number }\end{array}$ \\
\hline $087 \mathrm{M}^{\star}$ & EU306818 \\
\hline $621 A^{*}$ & EU306819 \\
\hline $635 A^{*}$ & EU306820 \\
\hline $670 \mathrm{~N}^{*}$ & EU306821 \\
\hline $818 \mathrm{E}^{\star}$ & EU306822 \\
\hline $856 \mathrm{~T}^{*}$ & EU306823 \\
\hline CECT 5173 & EU741642 \\
\hline $\begin{array}{l}\text { A. salmonicida subsp. achromogenes } \mathrm{LMG} \\
14900^{\mathrm{T}}\end{array}$ & EU306824 \\
\hline A. salmonicida subsp. masoucida CECT $896^{\mathrm{T}}$ & EU306825 \\
\hline A. salmonicida subsp. pectinolytica CECT $5752^{\mathrm{T}}$ & EU306827 \\
\hline A. salmonicida subsp. salmonicida CECT $894^{\mathrm{T}}$ & EU306828 \\
\hline A. salmonicida subsp. smithia CIP $104757^{\mathrm{T}}$ & EU306829 \\
\hline \multicolumn{2}{|l|}{ A. schubertii } \\
\hline CECT 4933 & EU741643 \\
\hline CECT 4934 & EU741644 \\
\hline CIP $103437^{\mathrm{T}}$ & EU306830 \\
\hline A. sharmana DSM $17445^{\mathrm{T}}$ & EU306831 \\
\hline \multicolumn{2}{|l|}{ A. simiae } \\
\hline CIP 107797 & EU306832 \\
\hline CIP $107798^{\mathrm{T}}$ & EU306833 \\
\hline \multicolumn{2}{|l|}{ A. sobria } \\
\hline CECT $4245^{\mathrm{T}}$ & EU306834 \\
\hline CECT 4248 & EU741645 \\
\hline A. trota CECT $4255^{\mathrm{T}}$ & EU306836 \\
\hline A. veronii biovar sobria CECT 4246 & EU306838 \\
\hline A. veronii biovar veronii CECT $4257^{\mathrm{T}}$ & EU306839 \\
\hline Aeromonas sp. HG11 CECT 4253 & EU306802 \\
\hline Aeromonas sp. HG13 CECT 4254 & EU306835 \\
\hline
\end{tabular}

${ }^{*}$ See Miñana-Galbis et al. $(2002,2004 b)$ for further information on these strains.

better discrimination than the $16 \mathrm{~S}$ rRNA gene between the species of the genus Aeromonas. Moreover, cpn60 UT sequences showed similar discriminatory power to that obtained with $g y r B$ and $r p o D$.

The mean DNA G $+\mathrm{C}$ content of the $c p n 60$ gene sequences $(59.6 \pm 0.3 \mathrm{~mol} \%)$ was within the range of $\mathrm{G}+\mathrm{C}$ content reported for the genus Aeromonas (57-63 mol\%; MartinCarnahan \& Joseph, 2005).

Peptide translations of the partial cpn60 sequences were also obtained. Of 185 amino acids, $153(82.7 \%)$ were conserved in all sequences, while $32(17.3 \%)$ showed variability, 16 of which were singleton sites. With the exception of $A$. sharmana, which exhibited a histidine residue in position 93 (codon 277, 278, 279), the translated peptide sequences lacked histidine and tryptophan residues.

\section{Phylogenetic relationships}

Fig. 2 shows the JC69 neighbour-joining tree obtained with the UT sequences of the cpn60 gene, clustering together all 
Table 2. Analysis of 35 Aeromonas sequences from $c p n 60$, gyrB, rpoD and $16 \mathrm{~S}$ rRNA genes

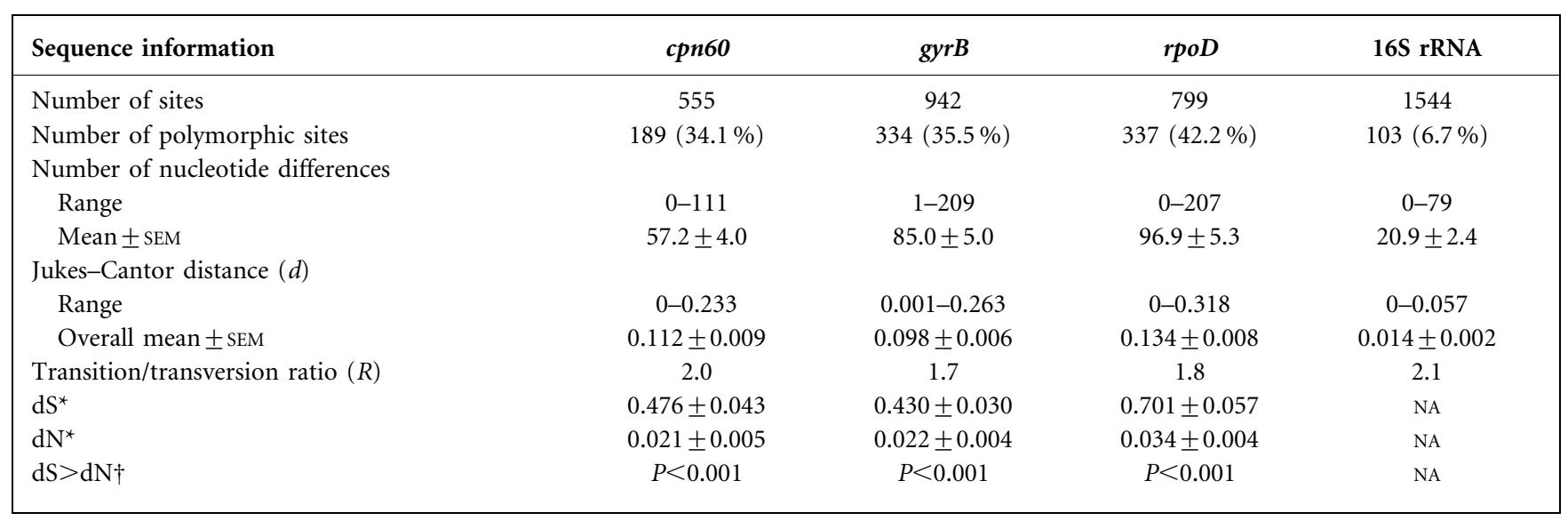

NA, Not applicable.

${ }^{*}$ Synonymous substitutions per synonymous site $(\mathrm{dS})$ and non-synonymous substitutions per non-synonymous site (dN) (means \pm SEM) (NeiGojobori method using Jukes-Cantor distance).

$\dagger$ Acceptance probability of a null hypothesis of $\mathrm{dS}=\mathrm{dN}$ with $\mathrm{dS}>\mathrm{dN}$ as the alternative hypothesis, using a $Z$-test.

of the Aeromonas species and subspecies with a bootstrap value of $92 \%$, except in the case of $A$. sharmana. Dendrograms generated by Kimura two-parameter, Tamura-Nei and maximum-parsimony showed almost identical topologies to that obtained using JC69 (not shown).

Aeromonas bivalvium and Aeromonas molluscorum strains clustered in separate groups in the dendrogram. These results were expected, since these species can be easily separated from the remaining Aeromonas species based on phenotypic characteristics, FAFLP fingerprinting and sequence analysis of genes such as $16 \mathrm{~S}$ rRNA, gyrB and
rpoD (Miñana-Galbis et al., 2004a, 2007; Saavedra et al., 2006). Five nucleotide differences ( $0.9 \%$ divergence) were observed between the two A. bivalvium strains, and 5-23 differences (0.9-4.3\% divergence) among the five $A$. molluscorum strains. Therefore, the cpn60 UT sequence afforded a clear differentiation between $A$. bivalvium and $A$. molluscorum strains.

Aeromonas caviae, A. media, A. eucrenophila and A. encheleia displayed related but different phylogenetic lines in the dendrogram (Fig. 2), with 27-45 interspecies nucleotide differences (4.6-8.6\% divergence). In agreement with previous studies (Huys et al., 1997; Soler et al.,
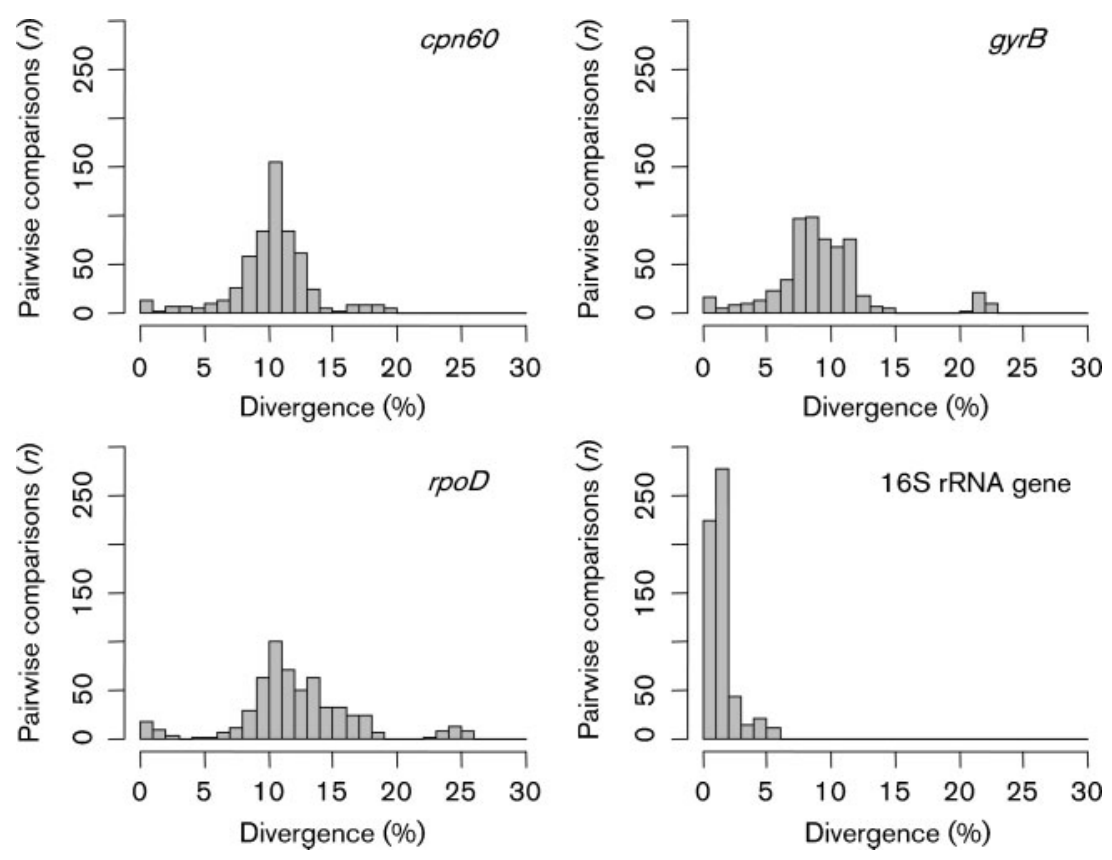

Fig. 1. Distribution of pairwise sequence divergence comparisons of cpn60, gyrB, $r p o D$ and $16 \mathrm{~S}$ rRNA genes. The horizontal axes represent classes of sequence divergence. 


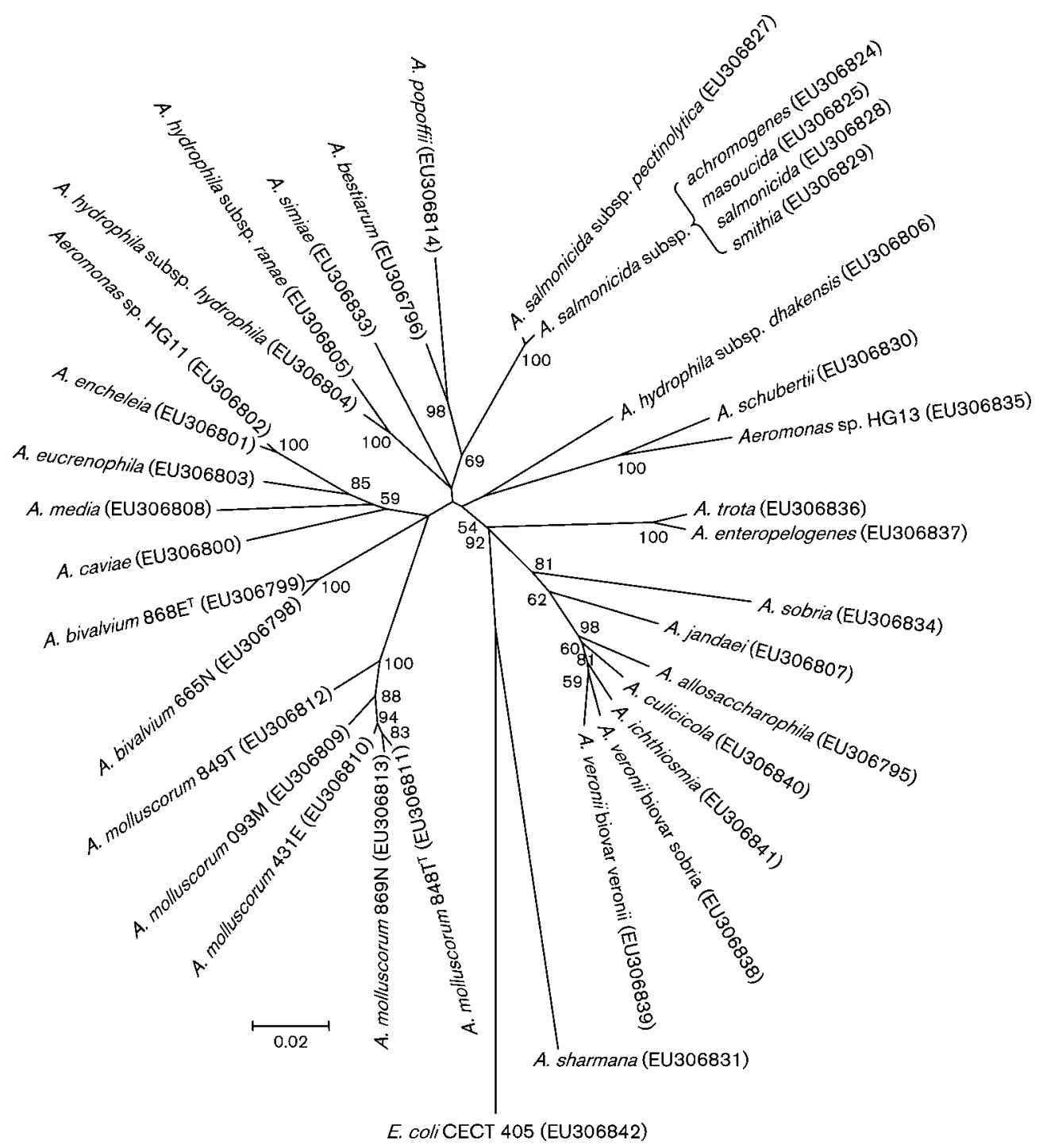

Fig. 2. Consensus neighbour-joining phylogenetic tree (JC69 distance) obtained from 35 cpn60 UT sequences, encompassing all of the species and subspecies of the genus Aeromonas. GenBank accession numbers are indicated in parentheses. Bar, distance of 0.02 , as calculated by MEGA. Bootstrap values ( $>50 \%)$ after 1000 replicates are shown as percentages. Further strain details are given in Table 1.

2004; Küpfer et al., 2006), Aeromonas HG11 (as represented by strain CECT 4253) can be regarded as belonging to A. encheleia based on cpn60 UT sequence analysis, since its sequence exhibits only four nucleotide differences ( $0.7 \%$ divergence) from that of the A. encheleia type strain.

UT sequences obtained from the type strains of the $A$. salmonicida subspecies were identical to the corresponding cpn60 gene sequence from the complete genome of $A$. salmonicida subsp. salmonicida A449 with the exception of A. salmonicida subsp. pectinolytica, which exhibited three nucleotide differences ( $0.5 \%$ divergence). This cluster was close to those of Aeromonas bestiarum and Aeromonas popoffii, with a bootstrap value of $69 \%$. UT sequences for these three species showed a divergence range of $5.4-9.6 \%$.
The sequence obtained from Aeromonas hydrophila subsp. hydrophila was identical to that from the complete genome of A. hydrophila subsp. hydrophila ATCC $7966^{\mathrm{T}}$. The A. hydrophila cluster grouped together the type strains of $A$. hydrophila subsp. hydrophila and A. hydrophila subsp. ranae, with 14 nucleotide differences (2.6\% divergence) between them, in a position close to the A. salmonicida group. However, the cpn60 UT sequence from the type strain of A. hydrophila subsp. dhakensis revealed 37-40 nucleotide differences $(7-7.6 \%$ divergence) when it was compared with those of the other A. hydrophila subspecies, thereby clustering this subspecies in a separate phylogenetic line. These results, together with those obtained for the $16 \mathrm{~S}$ rRNA, gyrB and rpoD genes (Miñana-Galbis et al., 2004a; D. Miñana-Galbis, M. Farfán, M. C. Fusté and J. G. Lorén, 
unpublished results), suggest that $A$. hydrophila subsp. dhakensis can be considered as a novel Aeromonas species.

The cpn60 UT sequence therefore allowed the accurate differentiation of species within the 'A. hydrophila complex' (Martínez-Murcia et al., 2005), similar to that obtained by FAFLP fingerprinting and sequence analysis of gyrB, dnaJ and rpoD (Huys \& Swings, 1999; Saavedra et al., 2006; Nhung et al., 2007). This result is remarkable since species of this complex, primarily A. salmonicida and A. bestiarum, are very difficult to distinguish by phenotypic identification, $16 \mathrm{~S}$ rRNA gene sequencing or DNA-DNA hybridization (Miñana-Galbis et al., 2002; Valera \& Esteve, 2002; Abbott et al., 2003; Martínez-Murcia et al., 2005). The type strain of Aeromonas simiae was also included in the group containing A. salmonicida, A. bestiarum, A. hydrophila and A. popoffii, albeit with a bootstrap value of $14 \%$.

The strain Aeromonas sp. CECT 4254 (HG13) clustered close to the type strain of Aeromonas schubertii (100 \% bootstrap) in a separate phylogenetic line, consistent with previous analyses (Hickman-Brenner et al., 1988; Martínez-Murcia, 1999; Miñana-Galbis et al., 2004a; Küpfer et al. 2006; Saavedra et al., 2006). Sequences obtained from these strains differed in 30 nucleotides (5.6\% divergence).

The type strain of Aeromonas trota joined to Aeromonas enteropelogenes in the same cluster ( $100 \%$ bootstrap). The two sequences differed by only 10 nucleotides $(1.8 \%$ divergence). Aeromonas enteropelogenes has been reported to be a later heterotypic synonym of Aeromonas trota (Collins et al., 1993; Huys et al., 2002),

All the type or reference strains of Aeromonas veronii bv. veronii, $A$. veronii bv. sobria, $A$. culicicola and $A$. ichthiosmia were clustered together, differing by $14-20$ nucleotides (2.6-3.7\% divergence). These results were expected, considering that Aeromonas ichthiosmia and Aeromonas culicicola are regarded as later heterotypic synonymous of Aeromonas veronii (Collins et al., 1993; Huys et al., 2001, 2005; Miñana-Galbis et al., 2004a). Moreover, Aeromonas allosaccharophila appeared in very close proximity to the $A$. veronii group ( $98 \%$ bootstrap) in the phylogenetic tree, differing by 20-24 nucleotides (3.7$4.5 \%$ divergence) with respect to $A$. veronii strains. This result suggests that $A$. allosaccharophila occupies a taxonomically uncertainty position with respect to $A$. veronii, which is consistent with AFLP genotyping and dnaJ sequencing studies (Huys et al., 1996; Nhung et al., 2007). Likewise, Aeromonas jandaei and A. sobria were located relatively close to the $A$. veronii group ( $81 \%$ bootstrap), in independent phylogenetic lines.

Recently, the taxonomic status of A. sharmana as a member of the genus Aeromonas has been questioned on the basis of 16S rRNA gene, $r p o D$ and gyrB sequences (MartínezMurcia et al., 2007; D. Miñana-Galbis, M. Farfán, M. C. Fusté and J. G. Lorén, unpublished results). Analysis of cpn60 UT sequences in Aeromonas has provided new evidence that $A$. sharmana can no longer be regarded as a member of this genus. In this study, the cpn60 UT sequence of A. sharmana DSM $17445^{\mathrm{T}}$ exhibited 86-111 nucleotide differences (17.4-23.3\% divergence), with a mean of $98.4 \pm 1.1 \quad(20.2 \pm 0.3 \%$ divergence). These values are significantly higher than the mean $(54.7 \pm 0.6 \mathrm{nt}$ or $10.6 \pm 0.1 \%$ divergence) obtained among the other Aeromonas species $(t$-test, $P<0.001)$. The A. sharmana UT sequence exhibited 29 unique nucleotides that were absent from the other Aeromonas sequences. This clear separation of A. sharmana from the genus Aeromonas can also be inferred from Fig. 2 and Supplementary Fig. S1. Furthermore, when we determined the amino acid composition of the UT sequences, A. sharmana was the only one to contain a histidine residue.

\section{Usefulness of cpn60 UT for Aeromonas species identification}

In order to validate the usefulness of cpn60 UT sequencing for Aeromonas identification, we sequenced 33 additional Aeromonas strains (Table 1). These 33 sequences, as well as two sequences obtained from the cpnDB (GenBank accession numbers AF030975 and DQ074967), were compared with the 35 Aeromonas sequences analysed previously in this work. The addition of the 33 new sequences did not modify the topology of the phylogenetic tree (Fig. 2 and Supplementary Fig. S2).

Based on the results obtained in this study, threshold values were established to permit Aeromonas species discrimination based on cpn60 UT sequence divergence. Intraspecific divergence rates were $\leqslant 3.5 \%$ ( $\leqslant 19$ nt differences), while interspecific divergence rates ranged from 3.7 to $16.9 \%$ (20$84 \mathrm{nt}$ differences), excluding $A$. sharmana (Table 3 ). These results were similar to those obtained from $d n a J$, gyrB and $r p o D$ sequence analyses, with interspecific threshold values of $5.2 \%$ for $d n a J$ and $3 \%$ for $g y r B$ and $r p o D$ (Soler et al., 2004; Nhung et al., 2007). The intraspecific threshold value showed three exceptions, since the A. culicicola and $A$. ichthiosmia cpn60 sequences exhibited a divergence of $3.7 \%$ and, in the case of A. molluscorum, the sequence of strain $849 \mathrm{~T}$ exhibited a divergence of $4.1 \%$ with respect to strain $869 \mathrm{~N}$ and $4.3 \%$ with respect to strain $848 \mathrm{~T}^{\mathrm{T}}$.

Pairwise comparison of cpn60 UT sequences also allowed us to discriminate between the type and reference strains of the different Aeromonas species, except in the case of $A$. salmonicida (Supplementary Fig. S2). Therefore, it was possible to differentiate between $A$. encheleia and Aeromonas sp. HG11, A. hydrophila subsp. hydrophila and A. hydrophila subsp. ranae, A. trota and A. enteropelogenes, A. veronii, A. culicicola, A. ichthiosmia, A. veronii bv. sobria and $A$. veronii bv. veronii. In the case of the A. salmonicida subspecies, all of them except $A$. salmonicida subsp. pectinolytica exhibited identical cpn60 sequences and therefore could not be differentiated.

In addition to other housekeeping genes such as $d n a J$, gyrB, $r p o B$ and rpoD (Küpfer et al., 2006; Saavedra et al., 2006; 
Table 3. Intra- and interspecific ranges of nucleotide differences and Jukes-Cantor distances of all cpn60 sequences analysed in this study

A. encheleia includes Aeromonas sp. HG11, A. hydrophila includes A. hydrophila subsp. hydrophila and A. hydrophila subsp. ranae, A. salmonicida includes A. salmonicida subsp. achromogenes, A. salmonicida subsp. masoucida, A. salmonicida subsp. pectinolytica, A. salmonicida subsp. salmonicida and A. salmonicida subsp. smithia, A. trota includes A. enteropelogenes and A. veronii includes A. culicicola, A. ichthiosmia, A. veronii biovar sobria and $A$. veronii biovar veronii. NA, Not applicable.

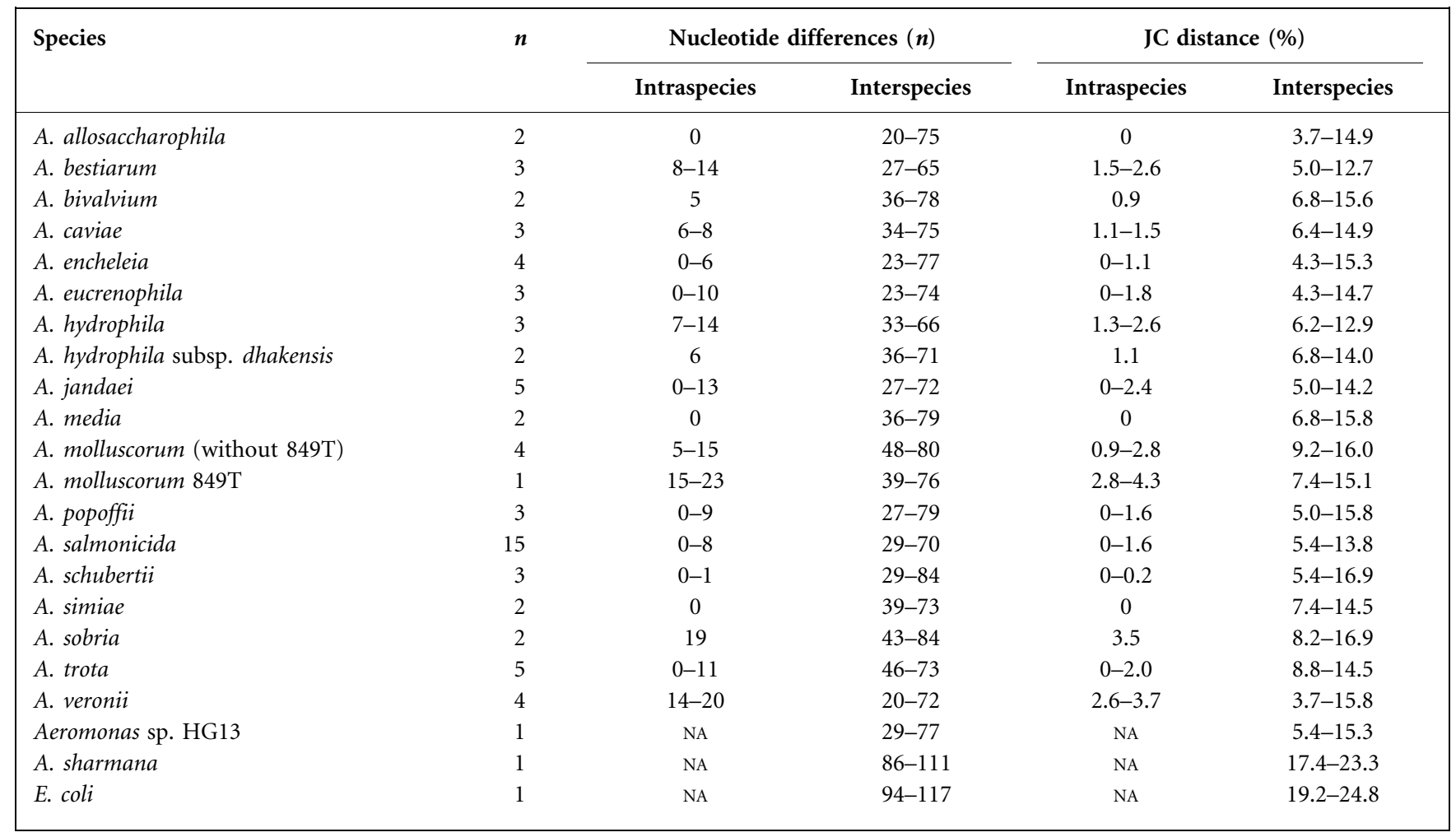

Nhung et al., 2007), the present study has demonstrated that cpn60 sequence analysis offers an effective method for discriminating species of Aeromonas, inferring their phylogenetic relationships and contributing to further taxonomic clarification of certain controversial taxa found in this genus. Furthermore, from an experimental standpoint, the determination of cpn60 UT sequences is a simple and rapid technique that requires a unique sequencing reaction, due to its own relatively short sequence (555 bp).

Finally, we recommend UT cpn60 gene sequencing be included in the description of any novel Aeromonas species, since it represents a suitable alternative for the identification and phylogenetic study of Aeromonas species. Moreover, cpn60 is a universal gene that allows the establishment of a web-based taxonomic database within the cpnDB (http://cpndb.cbr.nrc.ca).

\section{ACKNOWLEDGEMENTS}

We thank Marina Riera Munar and the Serveis Cientificotècnics of the Universitat de Barcelona (Unitat de Genòmica) for technical assistance. We thank Robin Rycroft for correcting the manuscript. This work has been supported by project CGL2004-03385/BOS from the Ministerio de Educación y Ciencia, Spain.

\section{REFERENCES}

Abbott, S. L., Cheung, W. K. W. \& Janda, J. M. (2003). The genus Aeromonas: biochemical characteristics, atypical reactions, and phenotypic identification schemes. J Clin Microbiol 41, 2348-2357.

Brousseau, R., Hill, J. E., Préfontaine, G., Goh, S. H., Harel, J. \& Hemmingsen, S. M. (2001). Streptococcus suis serotypes characterized by analysis of chaperonin 60 gene sequences. Appl Environ Microbiol 67, 4828-4833.

Collins, M. D., Martínez-Murcia, A. J. \& Cai, J. (1993). Aeromonas enteropelogenes and Aeromonas ichthiosmia are identical to Aeromonas trota and Aeromonas veronii, respectively, as revealed by small-subunit rRNA sequence analysis. Int J Syst Bacteriol 43, 855-856.

Esteve, C., Valera, L., Gutiérrez, C. \& Ventosa, A. (2003). Taxonomic study of sucrose-positive Aeromonas jandaei-like isolates from faeces, water and eels: emendation of A. jandaei Carnahan et al. 1992. Int J Syst Evol Microbiol 53, 1411-1419.

Fares, M. A. \& Travers, S. A. (2006). A novel method for detecting intramolecular coevolution: adding a further dimension to selective constraints analyses. Genetics 173, 9-23.

Goyal, K., Qamra, R. \& Mande, S. C. (2006). Multiple gene duplication and rapid evolution in the groEL gene: functional implications. J Mol Evol 63, 781-787.

Gupta, R. S. \& Sneath, P. H. (2007). Application of the character compatibility approach to generalized molecular sequence data: branching order of the proteobacterial subdivisions. J Mol Evol 64, 90-100. 
Hickman-Brenner, F. W., Fanning, G. R., Arduino, M. J., Brenner, D. J. \& Farmer, J. J., III (1988). Aeromonas schubertii, a new mannitolnegative species found in human clinical specimens. J Clin Microbiol 26, 1561-1564.

Hill, J. E., Seipp, R. P., Betts, M., Hawkins, L., Van Kessel, A. G., Crosby, W. L. \& Hemmingsen, S. M. (2002). Extensive profiling of a complex microbial community by high-throughput sequencing. Appl Environ Microbiol 68, 3055-3066.

Hill, J. E., Penny, S. L., Crowell, K. G., Goh, S. H. \& Hemmingsen, S. M. (2004). cpnDB: a chaperonin sequence database. Genome Res 14, 1669-1675.

Hill, J. E., Paccagnella, A., Law, K., Melito, P. L., Woodward, D. L., Price, L., Leung, A. H., Ng, L. K., Hemmingsen, S. M. \& Goh, S. H. (2006). Identification of Campylobacter spp. and discrimination from Helicobacter and Arcobacter spp. by direct sequencing of PCRamplified cpn60 sequences and comparison to $\mathrm{cpnDB}$, a chaperonin reference sequence database. J Med Microbiol 55, 393-399.

Horwich, A. L., Fenton, W. A., Chapman, E. \& Farr, G. W. (2007). Two families of chaperonin: physiology and mechanism. Annu Rev Cell Dev Biol 23, 115-145.

Huys, G. \& Swings, J. (1999). Evaluation of a fluorescent amplified fragment length polymorphism (FAFLP) methodology for the genotypic discrimination of Aeromonas taxa. FEMS Microbiol Lett 177, 83-92.

Huys, G., Coopman, R., Janssen, P. \& Kersters, K. (1996). Highresolution genotypic analysis of the genus Aeromonas by AFLP fingerprinting. Int J Syst Bacteriol 46, 572-580.

Huys, G., Kämpfer, P., Altwegg, M., Coopman, R., Janssen, P., Gillis, M. \& Kersters, K. (1997). Inclusion of Aeromonas DNA hybridization group 11 in Aeromonas encheleia and extended descriptions of the species Aeromonas eucrenophila and A. encheleia. Int J Syst Bacteriol 47, 1157-1164.

Huys, G., Kämpfer, P. \& Swings, J. (2001). New DNA-DNA hybridization and phenotypic data on the species Aeromonas ichthiosmia and Aeromonas allosaccharophila: A. ichthiosmia Schubert et al. 1990 is a later synonym of A. veronii HickmanBrenner et al. 1987. Syst Appl Microbiol 24, 177-182.

Huys, G., Denys, R. \& Swings, J. (2002). DNA-DNA reassociation and phenotypic data indicate synonymy between Aeromonas enteropelogenes Schubert et al. 1990 and Aeromonas trota Carnahan et al. 1991. Int J Syst Evol Microbiol 52, 1969-1972.

Huys, G., Cnockaert, M. \& Swings, J. (2005). Aeromonas culicicola Pidiyar et al. 2002 is a later subjective synonym of Aeromonas veronii Hickman-Brenner et al. 1987. Syst Appl Microbiol 28, 604-609.

Ihaka, R. \& Gentleman, R. (1996). R: a language for data analysis and graphics. J Comput Graph Stat 5, 299-314.

Jukes, T. H. \& Cantor, C. R. (1969). Evolution of protein molecules. In Mammalian Protein Metabolism, vol. 3, pp. 21-132. Edited by H. N. Munro. New York: Academic Press.

Kumar, S., Tamura, K. \& Nei, M. (2004). MEGA3: integrated software for molecular evolutionary genetics analysis and sequence alignment. Brief Bioinform 5, 150-163.

Küpfer, M., Kuhnert, P., Korczak, B. M., Peduzzi, R. \& Demarta, A. (2006). Genetic relationships of Aeromonas strains inferred from $16 \mathrm{~S}$ rRNA, gyrB and $r p o B$ gene sequences. Int J Syst Evol Microbiol 56, 2743-2751.

Martin-Carnahan, A. \& Joseph, S. W. (2005). Genus I. Aeromonas Stanier 1943, 213 ${ }^{\mathrm{AL}}$. In Bergey's Manual of Systematic Bacteriology, 2nd edn, vol. 2, part B, pp. 557-578. Edited by G. M. Garrity, D. J. Brenner, N. R. Krieg \& J. T. Staley. New York: Springer.
Martínez-Murcia, A. J. (1999). Phylogenetic positions of Aeromonas encheleia, Aeromonas popoffii, Aeromonas DNA hybridization group 11 and Aeromonas group 501. Int J Syst Bacteriol 49, 1403-1408.

Martínez-Murcia, A. J., Soler, L., Saavedra, M. J., Chacón, M. R., Guarro, J., Stackebrandt, E. \& Figueras, M. J. (2005). Phenotypic, genotypic, and phylogenetic discrepancies to differentiate Aeromonas salmonicida from Aeromonas bestiarum. Int Microbiol 8, 259-269.

Martínez-Murcia, A. J., Figueras, M. J., Saavedra, M. J. \& Stackebrandt, E. (2007). The recently proposed species Aeromonas sharmana sp. nov., isolate GPTSA $-6^{\mathrm{T}}$, is not a member of the genus Aeromonas. Int Microbiol 10, 61-64.

Miñana-Galbis, D., Farfán, M., Lorén, J. G. \& Fusté, M. C. (2002). Biochemical identification and numerical taxonomy of Aeromonas spp. isolated from environmental and clinical samples in Spain. J Appl Microbiol 93, 420-430.

Miñana-Galbis, D., Farfán, M., Fusté, M. C. \& Lorén, J. G. (2004a). Aeromonas molluscorum sp. nov., isolated from bivalve molluscs. Int $J$ Syst Evol Microbiol 54, 2073-2078.

Miñana-Galbis, D., Farfán, M., Fusté, M. C. \& Lorén, J. G. (2004b). Genetic diversity and population structure of Aeromonas hydrophila, Aer. bestiarum, Aer. salmonicida and Aer. popoffii by multilocus enzyme electrophoresis (MLEE). Environ Microbiol 6, 198-208.

Miñana-Galbis, D., Farfán, M., Fusté, M. C. \& Lorén, J. G. (2007). Aeromonas bivalvium sp. nov., isolated from bivalve molluscs. Int $J$ Syst Evol Microbiol 57, 582-587.

Nei, M. (1996). Phylogenetic analysis in molecular evolutionary genetics. Annu Rev Genet 30, 371-403.

Nhung, P. H., Hata, H., Ohkusu, K., Noda, M., Shah, M. M., Goto, K. \& Ezaki, T. (2007). Use of the novel phylogenetic marker dnaJ and DNA-DNA hybridization to clarify interrelationships within the genus Aeromonas. Int J Syst Evol Microbiol 57, 1232-1237.

Rozas, J. \& Rozas, R. (1999). DnaSP version 3: an integrated program for molecular population genetics and molecular evolution analysis. Bioinformatics 15, 174-175.

Saavedra, M. J., Figueras, M. J. \& Martínez-Murcia, A. J. (2006). Updated phylogeny of the genus Aeromonas. Int J Syst Evol Microbiol 56, 2481-2487.

Soler, L., Yáñez, M. A., Chacon, M. R., Aguilera-Arreola, M. G., Catalán, V., Figueras, M. J. \& Martínez-Murcia, A. J. (2004). Phylogenetic analysis of the genus Aeromonas based on two housekeeping genes. Int J Syst Evol Microbiol 54, 1511-1519.

Stackebrandt, E., Frederiksen, W., Garrity, G. M., Grimont, P. A. D., Kämpfer, P., Maiden, M. C. J., Nesme, X., Rosselló-Mora, R., Swings, J. \& other authors (2002). Report of the ad hoc committee for the re-evaluation of the species definition in bacteriology. Int $J$ Syst Evol Microbiol 52, 1043-1047.

Thompson, J. D., Higgins, D. G. \& Gibson, T. J. (1994). CLUSTAL W: improving the sensitivity of progressive multiple sequence alignment through sequence weighting, position-specific gap penalties and weight matrix choice. Nucleic Acids Res 22, 4673-4680.

Thompson, J. R., Pacocha, S., Pharino, C., Klepac-Ceraj, V., Hunt, D. E., Benoit, J., Sarma-Rupavtarm, R., Distel, D. L. \& Polz, M. F. (2005). Genotypic diversity within a natural coastal bacterioplankton population. Science 307, 1311-1313.

Valera, L. \& Esteve, C. (2002). Phenotypic study by numerical taxonomy of strains belonging to the genus Aeromonas. J Appl Microbiol 93, 77-95.

Wick, G., Knoflach, M. \& Xu, Q. (2004). Autoimmune and inflammatory mechanisms in atherosclerosis. Annu Rev Immunol 22, 361403. 